\title{
Response of different chemicals on vase life and petals quality of Oriental lily cv. 'Crystal blanca'
}

Muhammad Tariq ${ }^{1 *}$, Naveed Ahmad ${ }^{2}$, Muhammad Saleem Akhtar Khan $^{2}$, Osama Bin Abdul Hafeez ${ }^{1}$, Muhammad Mahmood-ur-Rehman ${ }^{1}$, Muhammad Awais Ghani ${ }^{1}$, Mubashir Zahid ${ }^{1}$ and Muhammad Jahanzeb

Anwar ${ }^{1}$

1. Institute of Horticultural Sciences, University of Agriculture Faisalabad-Pakistan

2. Directorate of Floriculture (Training and Research) Lahore, Punjab-Pakistan

*Corresponding author's email: taq.3559@ hotmail.com

Citation

Muhammad Tariq, Naveed Ahmad, Muhammad Saleem Akhtar Khan, Osama Bin Abdul Hafeez, Muhammad Mahmood-ur-Rehman, Muhammad Awais Ghani, Mubashir Zahid and Muhammad Jahanzeb Anwar. Response of different chemicals on vase life and petals quality of oriental lily cv. 'Crystal blanca'. Pure and Applied Biology. Vol. 6, Issue 3, pp976-980. http://dx.doi.org/10.19045/bspab.2017.600103

\begin{tabular}{llll}
\hline \hline Received: 07/02/2017 & Revised: 19/07/2017 & Accepted: 04/08/2017 & Online First: 07/08/2017 \\
\hline
\end{tabular}

\section{Abstract}

Lilium is one of the foremost cut flowers in the international market. The main problem is blockage of xylem vessels and insufficient water uptake takes part in the short vase life of cut flowers. An investigation was made to study the effect of preservative and biocides such as Sucrose (4 mg), Aluminum Sulfate (60 mg), $\mathrm{CaCl}_{2} \cdot 2 \mathrm{H}_{2} \mathrm{O}(30 \mathrm{mg}), \mathrm{CuSO}_{4}(90 \mathrm{mg})$ and Ethanol $(6 \mathrm{ml})$ on vase life of Oriental lily cv. 'Crystal Blanca'. Postharvest characteristics such as vase life, solution uptake and petal quality were evaluated. The experiment was laid out according to Complete Randomized Design (CRD) with six treatments and three replications and Tukey test was applied to check the differences among treatments. Maximum vase life in terms of days was observed in treatment Sucrose (9.33 days) followed by Aluminum Sulfate (7.00 days) and Ethanol (6.33 days). Maximum solution uptake was also recorded in $\mathrm{CaCl}_{2} \cdot 2 \mathrm{H}_{2} \mathrm{O}(151.67 \mathrm{ml})$ followed by Ethanol $(106.67 \mathrm{ml})$. In present context, sucrose treatment was distinctly able to enhance the vase life of Oriental Lilly and it could be a source to increase the value of this flower Keywords: Lilium; Vase life; Petals quality; Sucrose; Aluminum sulfate; Ethanol

\section{Introduction}

In past, cut flowers were kept in simple water but with the passage of time, scientists introduced many floral preservatives and biocides to increase the vase life and quality of cut flowers. Several preservatives and biocides i.e. Silver Nitrate, Aluminum Sulfate, Cobalt Sulfate, 8-hydroxyquinoline Sulfate, Boric Acid, Citric Acid, Ascorbic
Acid, Sucrose, Supper Sulfate and Ethanol etc. have been used in different formulation and their combination to increase the vase life of different cut flowers.

Lilium longiflorum belongs to family Liliaceae and is an important commercial flower of the world. Usually, it is harvested at tight bud stage for export markets, while at flower opening stage for local markets. 
However, postharvest senescence is a major limiting factor for its export which is further exacerbated with ethylene production [1]. It is native to Islands South of Japan is an important flowering crop having a great commercial value as a cut flower due to its excellent keeping quality, colors and flower arrangements. It should be harvested at (when flower bud shows its color for distinct or export market and flower opening stage for local market). The appearance of bent neck, wilting of outer petals and yellowing of the leaves indicate the end of the useful vase life of cut flowers [2,3].

Flower quality and vase life are two most important factors responsible for good export of this cut flower [4]. Vase life of cut flowers is mainly reduced due to bacterial and fungal infection, maturation and aging of plant, severe physical injuries, ethylene accumulation, wilting due to water stress and plugging of xylem [5]. Similarly, the quality of cut flower depends on cultivated conditions, nutritional status and ethylene gas accumulation [6]. Ethylene causes premature wilting, color fading, abscission of flower petals and leaf yellowing. Dirty containers and reused solutions may contain microbes that clog the stem and obstruct water uptake, so blockages of water in xylem vessels contribute to the short postharvest life of many cut flowers [7].

Carbohydrates are very important for maintenance of turgor pressure so quality and vase life of a flower can be significantly increased by supplying sucrose or/with some other ethylene inhibiting chemicals $[8,9]$. The addition of sugar to vase solution not only restored the color of the petals but also increased the size of the opening flowers [10]. Gibberellin $\left(\mathrm{GA}_{3}\right)$, Cytokinin's (benzyl adenine), bactericides (8-HQS), Silver thiosulfate (STS) used to improve the flower quality and resulted in extended the vase life (11.50, 11.26 days) compared with control (8.13 days) [11].
An experiment was conducted to extend the vase life of lily. The main objective of the study was to investigate the effect of various concentrations of sucrose, copper sulfate, dehydrate calcium chloride, aluminum sulfate and ethanol on the flower quality and vase life of lily cut flower.

\section{Materials and methods}

The present investigation was carried out to study the postharvest performance of oriental lily under different chemical treatments. Opened flowers of oriental lily cv. 'Crystal blanca' were obtained from research area and were brought to post harvest laboratory, Directorate of Floriculture (Training and Research) Lahore. In laboratory, uniform good quality flowers were selected and lower-most leaves from all stems were trimmed off (keeping 35 $\mathrm{cm}$ from bottom). Flowering stocks were provided with a slanting cut 1 inch from base under distilled water to avoid air embolism. Single flower was placed in single vase and was considered as an experimental unit. Solutions were made by adding following concentration of chemicals into $250 \mathrm{ml}$ distilled water (Table 1).

Flowers were kept at average $25{ }^{\circ} \mathrm{C} \pm 1{ }^{\circ} \mathrm{C}$ and $56.5 \% \mathrm{RH}$ for 10 days. Flowers quality was evaluated on daily basis using 4 grade scales.

Flowers were evaluated daily till they were found unfit for containing in vase. Vase life was recorded from the time of harvest to the time when $60 \%$ petal color became fade. The solution uptake was observed of every treatment in the vase containing $250 \mathrm{ml}$ solution until end of vase life duration. Therefore, water uptake of every treatment was calculated by subtracting their remaining solution in vase from total $250 \mathrm{ml}$ volume solution. Petals quality was assessed by making 4 grade systems (excellent $=4$, $\operatorname{good}=3$, Fair $=2$ and poor $=1$ ) with the passage of time. Quality inspection was 
done daily and grades were assigned according to their changing petal quality.

The experiment was conducted in Completely Randomized Design and Tukey test was employed to determine differences in treatment means at 5\% level of significance.

Table 1. Details of treatments

\begin{tabular}{|l|c|}
\hline Treatments & Chemicals with concentrations \\
\hline 1 & Control (Distilled Water) \\
\hline 2 & Sucrose $\left(4 \mathrm{mg} / 250 \mathrm{ml} \mathrm{H}_{2} \mathrm{O}\right)$ \\
\hline 3 & Aluminium sulfate $\left(60 \mathrm{mg} / 250 \mathrm{ml} \mathrm{H}_{2} \mathrm{O}\right)$ \\
\hline 4 & $\mathrm{CaCl}_{2} .2 \mathrm{H}_{2} \mathrm{O}\left(30 \mathrm{mg} / 250 \mathrm{ml} \mathrm{H}_{2} \mathrm{O}\right)$ \\
\hline 5 & Copper Sulfate $\left(90 \mathrm{mg} / 250 \mathrm{ml} \mathrm{H}_{2} \mathrm{O}\right)$ \\
\hline 6 & Ethanol $\left(6 \mathrm{ml} / 250 \mathrm{ml} \mathrm{H}_{2} \mathrm{O}\right)$ \\
\hline
\end{tabular}

\section{Results and discussion \\ Vase life}

Significant differences in treatment means were observed in vase life of flowers. Results revealed that sucrose had maximum vase life (9 days) followed by Aluminum Sulfate (7 days), ethanol (6.66) and $\mathrm{CaCl}_{2} .2 \mathrm{H}_{2} \mathrm{O}$ (5.66 days) while, minimum vase life was observed in Control (3.66 days) and followed by copper sulfate (4.66 days) (Figure 1). Sucrose supplies the energy and carbon skeletons required for bud opening. Sucrose is necessary for the maintenance of turgor pressure and flower opening [9]. Aluminum Sulfate has been recommended for vase life extension of several cut flowers and is used as an antimicrobial compound in preservative solution [12]. In case of ethanol; our result is dissimilar, as $6 \%$ ethanol had significantly increased vase life up 12.33 days [13]. Results were supported to the findings of [14] who concluded that sucrose solution $(40 \mathrm{mM})$ increased the vase life of Alstroemeria as compared to the control.

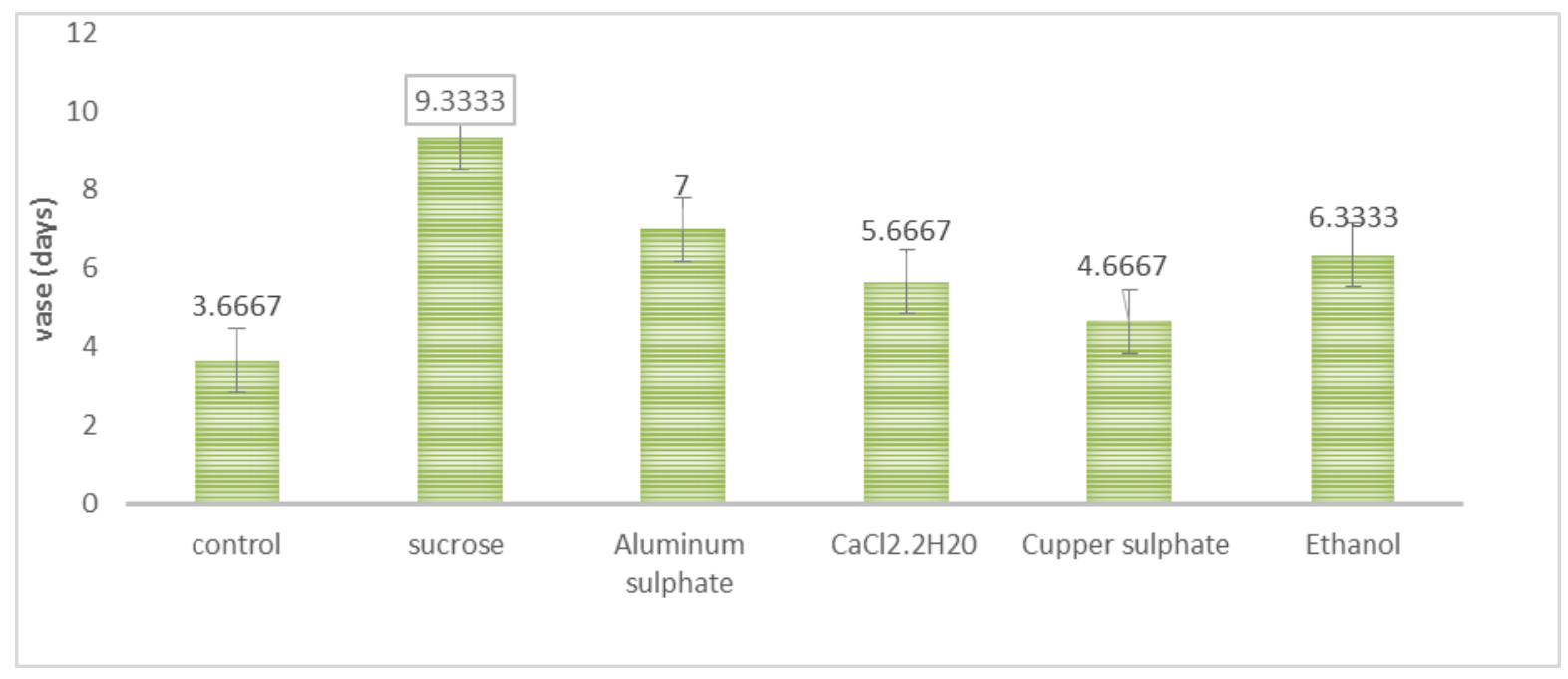

Figure 1. Effect of different chemicals on vase life and petals quality of oriental lily cv. 'Crystal blanca' 


\section{Water uptake}

The maximum solution uptake was observed in flower kept in $\mathrm{CaCl}_{2} .2 \mathrm{H}_{2} \mathrm{O}(151.67 \mathrm{ml})$, ethanol $(106.67 \mathrm{ml})$ and aluminum sulfate $(98.33 \mathrm{ml})$, minimum uptake was calculated in control $(61.67 \mathrm{ml})$ followed by Sucrose (95 ml) (Figure 2). It was observed that ethanol plays effective role in water uptake. Basically, ethanol decreases ethylene production and increase water uptake [13]. Aluminum sulfate acidifies vase solution, diminishes bacterial proliferation and enhances water uptake [15]. Results were supported with the findings of [16] who recorded the maximum water uptake by cut spikes of tuberose in $\mathrm{CaCl} 2.2 \mathrm{H} 2 \mathrm{O} ; 750 \mathrm{ppm}$ and $\mathrm{CaCl} 2.2 \mathrm{H} 2 \mathrm{O} ; 1000$ ppm.

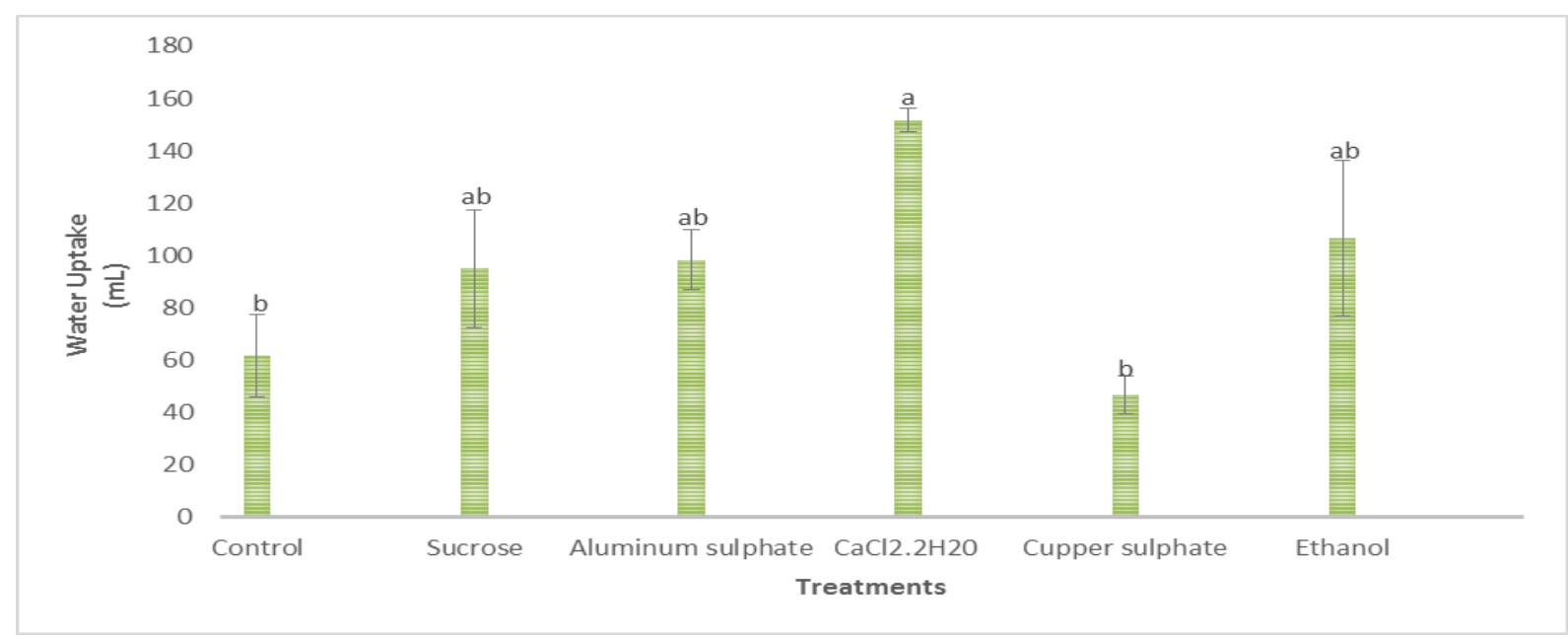

Figure 2. Effect of different chemicals on water uptake of oriental lily cv. 'Crystal blanca'

\section{Petals quality index}

During this research, petal quality index made on the basis of changing of petal color with the passage of days. For this purpose, four parameters were made on the basis of petals quality such as excellent, good, fair and poor and they were given number as 4 , 3,2 and 1 depending upon petals performance with passage of days. Severe changes in petals quality of $\mathrm{T}_{1}$ (control) was observed on third day of experiment. Quality of petals of Sucrose started to change after 7 days followed by Aluminum sulfate (5 days) (Table 2). Mahmood et al. [17] showed that quality of Carnation cut flowers deteriorated slowly and there was no change in quality up third day in case of $6 \%$ sucrose $+\mathrm{CuSO}_{4} 400 \mathrm{ppm}$ treatment.

Table 2. Effect of different chemicals on petals quality index of oriental lily cv. 'Crystal blanca'

\begin{tabular}{|c|c|c|c|c|c|c|c|c|c|c|c|}
\hline \multirow[t]{2}{*}{ Treatments } & \multicolumn{10}{|c|}{ Days } & \multirow[t]{2}{*}{ Means } \\
\hline & 1 & 2 & 3 & 4 & 5 & 6 & 7 & 8 & 9 & 10 & \\
\hline Control & $4.00 \mathrm{a}$ & $4.00 \mathrm{a}$ & $3.33 \mathrm{abc}$ & $1.66 \mathrm{de}$ & $1.00 \mathrm{e}$ & $1.00 \mathrm{e}$ & $1.00 \mathrm{e}$ & $1.00 \mathrm{e}$ & $1.00 \mathrm{e}$ & $1.00 \mathrm{e}$ & $1.89 \mathrm{~d}$ \\
\hline Sucrose & $4.00 \mathrm{a}$ & $4.00 \mathrm{a}$ & $4.00 \mathrm{a}$ & $4.00 \mathrm{a}$ & $4.00 \mathrm{a}$ & $4.00 \mathrm{a}$ & $3.33 \mathrm{abc}$ & $2.33 \mathrm{bcde}$ & $2.00 \mathrm{cde}$ & $1.00 \mathrm{e}$ & $3.26 \mathrm{a}$ \\
\hline $\begin{array}{l}\text { Aluminum } \\
\text { sulfate }\end{array}$ & $4.00 \mathrm{a}$ & $4.00 \mathrm{a}$ & $4.00 \mathrm{a}$ & $4.00 \mathrm{a}$ & $4.00 \mathrm{a}$ & $3.33 a b c$ & $2.00 \mathrm{cde}$ & $1.66 \mathrm{de}$ & $1.00 \mathrm{e}$ & $1.00 \mathrm{e}$ & $2.90 \mathrm{~b}$ \\
\hline $\mathrm{CaCl}_{2} \cdot 2 \mathrm{H}_{2} \mathrm{O}$ & $4.00 \mathrm{a}$ & $4.00 \mathrm{a}$ & $3.66 \mathrm{ab}$ & $3.66 \mathrm{ab}$ & $3.33 \mathrm{abc}$ & $2.66 \mathrm{abcd}$ & $2.00 \mathrm{cde}$ & $1.00 \mathrm{e}$ & $1.00 \mathrm{e}$ & $1.00 \mathrm{e}$ & $2.63 \mathrm{bc}$ \\
\hline Copper Sulfate & $4.00 \mathrm{a}$ & $4.00 \mathrm{a}$ & $4.00 \mathrm{a}$ & $3.66 \mathrm{ab}$ & $2.66 \mathrm{abcd}$ & 1.66de & $1.00 \mathrm{e}$ & $1.00 \mathrm{e}$ & $1.00 \mathrm{e}$ & $1.00 \mathrm{e}$ & $2.39 \mathrm{c}$ \\
\hline Ethanol & $4.00 \mathrm{a}$ & $4.00 \mathrm{a}$ & $4.00 \mathrm{a}$ & $3.66 \mathrm{ab}$ & $3.33 \mathrm{ab}$ & $3.00 \mathrm{abc}$ & 2.33 bcde & $1.00 \mathrm{e}$ & $1.00 \mathrm{e}$ & $1.00 \mathrm{e}$ & $2.73 \mathrm{bc}$ \\
\hline Means & $4.00 \mathrm{a}$ & $4.00 \mathrm{a}$ & $3.66 \mathrm{ab}$ & $3.44 \mathrm{bc}$ & $3.16 \mathrm{c}$ & $2.66 \mathrm{~d}$ & $1.94 \mathrm{e}$ & $1.33 \mathrm{f}$ & $1.16 \mathrm{f}$ & $1.00 \mathrm{e}$ & \\
\hline
\end{tabular}

Note: Values sharing similar letters are statistically alike in each column 


\section{Conclusion}

In current experiment, sucrose treatment increased the vase life of Oriental Lily from 3 days (control) to 9 days and with Aluminum sulfate up to 7 days which was a remarkable improvement in term of shelf life. In this scenario, we may conclude that Sucrose and Aluminum sulfate can be effectively used for improvement of vase life and petal quality of "Oriental Lily cv. Crystal Blanca".

\section{Authors' contributions}

Conceived and designed the experiments: $\mathrm{N}$ Ahmad, Performed the Experiments: M Tariq, M Zahid \& M Jahanzeb, Analyzed the Data: OBA Hafeez, Contributed reagents/ materials/ analysis tools: MSA Khan, Wrote the paper: MM Rehman, MA Ghani \& M Tariq.

\section{References}

1. Badiyan D, Wills RBH \& Bowyer MC (2004). Use of Nitric Oxide Donor Compound to extend the vase life of cut flowers. Hort Sci 39(6): 1371-1372.

2.Ketsa S \& Narkuba N (2011). Effects of amino acid and sucrose on vase life of cut roses. Acta Hort 543: 227-234.

3.Ried MS (2002). Non-metabolized cytokinins as a growth regulators in postharvest performance of ornamental. J Am Soc Hortic Sci 649: 201-205.

4. Kim JH, Lee AK \& Suh JK (2005). Effect of certain pre-treatment substances on vase life and physiological character in Lilium spp. Acta Hort 673: 9th International Symposium on Flower Bulbs, 307-314 (DOI: 10.17660/Acta Horticulture, 2005.673.39)

5. Sadek HR (2005). Postharvest studies on some important flower crops. Doctoral dissertation, Faculty of Horticultural Science, Corvinus University of Budapest, Hungary.

6.Jones ML, Kim ES \& Newman SE (2011). Role of ethylene and 1-MCP in flower development and petals abscission in zonal Geraniums. Hort Sci 3670: 1305-1309.

7.Jedrzerjuk A \& Zakrzewski J (2009). Xylem occlusion in the stems of common Lilac during postharvest life. Acta Physiol 31: 1147-1153.
8.Joseph BD \& Jini SS (2010). Insight into the role of exogenous salicylic acid on plants grown under salt environment. Asian J Crop Sci 2: 226-235.

9.Han SS (2003). Role of sugar in vase Solution on postharvest flower and leaf quality of Lily Stargaze. Hort Sci 38: 412-6.

10. EL-Shoura HAS, Elsherif MH \& Zaki AA (2013). The role of growth regulator preservative solutions on vase life and flower quality of Asiatic lily. Res J Agric Biol Sci 9(5): 218-222.

11. Sarkka L (2005). Yield, Quality and vase life of cut roses in year round greenhouse production. Academic Dissertation, University of Helsinki, Finland 64pp.

12. Ichmiura $K$, Taguchi $M$ \& Nonrikoshi $R$ (2006). Extension of the vase life in Cut Roses with glucose, Isothiazolinic germicide, citric acid and aluminum sulfate. Japan Agric Res Quarterly 40(3): 263-269.

13. Farokhzad A, Khalighi A, Mostofia Y \& Naderi R (2005). Role of ethanol in the vase lifeand ethylene production in cut Lisianthus (Eustoma grandiflorom Mariachii.cv.blue) Flowers. J Agric Soc Sci 1(4): 309-312.

14. Asil MH \& Roein Z (2012). Beneficial effect of carbohydrates solution on postharvest characteristics of cut Alstromeria. South western J Horti Bio Environ 3(1): 2012.

15. Anjum A, Naveed MF, Shakeel F \& Amin SH (2001). Effect of some chemicals on keeping quality and vase life of tuberose (Polianthus tuberose L.) cut flowers. J Res 12(1): 01-07.

16. Hassanpour AM, Hatamzadeh A \& Nakhi F (2004). Study on the effect of temperature and various chemicals treatments to Increase vase life of cut Rose flower "Baccra". Agric Sci Res J Guilan Agriculture Faculty 1(4): 121-129

17. Mahmood MA, Khan AS, Ahmad N \& Arshad M (2015). Keeping quality and vase life of Carnation cv. 'Eskimo' as influenced by different Chemicals. J Ornam Pl 5(1): 15-20. 